\title{
ДЕТЕРМІНАНТИ ВЧИНЕННЯ РОЗБІЙНИХ НАПАДІВ НА ЖИТЛО ГРОМАДЯН
}

\author{
СВІР Павло Володимирович - здобувач Донецького юридичного інституту \\ МВС України \\ DOI:10.32782/LAW.2020.1.22 \\ УДК 343.915
}

\begin{abstract}
У статті проведено розподіл детермінуючих факторів вчинення розбійних нападів на житло громадян на шість груп: економічні, сочіальні, політичні, організаційні, морально-психологічні та технічні. Основний вплив на аналізовані злочини здійснюють причини та умови, що стосуються економічної (криміналізачія економіки, диференціачія $i$ поляризація населення за доходами, безробіття і негативні процеси, які отримали свій розвиток в умовах бінансово-економічної кризи) та організачійної груп (ребормування правоохоронних органів). Встановлено, що виникнення кримінальних груп, щзо спеціалізуються на вчиненні розбійних нападів на житло громадян відбувається на основі кримінальноӥ спільності окремих осіб, що прагнуть до отримання злочинного прибутку. У процесі спілкування таких осіб відбувається раціональний, емоиійний $і$ вольовий взаємовплив та взаємодія індивідів, яка досягається взаєморозумінням, створюються умови згуртованості й солідарності, шо характеризують групову й колективну діяльність.

Ключові слова: розбій, власність, житло, детермінанти, причини, умови, запобігання.
\end{abstract}

Як відомо одним із елементів кримінологічної характеристики злочинності є визначення іiі детермінуючих чинників. Слід підкреслити, що проблема детермінації злочинності в цілому, окремих іiі видів і конкретного злочину є однією 3 центральних проблем кримінології. Важливість цієї проблеми полягає в тому, що без ії розв'язання практично неможливе ефективне запобігання злочинам.

У системі суспільних відносин криміногенні та антикриміногенні явища і процеси взаємопов'язані та співвідносяться як діалектичні протилежності. Вони одночасно впливають на суспільну свідомість, однак відображаються, сприймаються та оцінюються колективним розумом по-різному. Внаслідок цього криміногенні явища і процеси закономірно детермінують вибір протиправного шляху досягнення цілей лише певної частини людей, у першу чергу тих, котрі мають антисуспільну спрямованість свідомості [1].

Найчастіше терміном «детермінанти злочинності» у науковій літературі охоплюються причини та умови вчинення злочинів. На думку О. М. Джужі, причинами злочинності є такі процеси і явища, які породжують злочинність як свій безпосередній наслідок [2, c. 79].

Причини і умови злочинності криються у всій сукупності негативних явищ в суспільстві, і саме вони обумовлюють існування злочинності як свого наслідку. В кримінології існує й така думка, що причиною, яка найбільше впливає на вчинення кримінальнокараного діяння є антисоціальна мотивація поведінки [3, с. 56]. I на це положення необхідно звернути особливу увагу бо в одних і тих самих умовах, одні особи йдуть на вчинення корисливого злочину, а інші так і залишаються законослухняними громадянами. 
Щодо причин та умов злочинів проти власності та розбоїв взагалі, зауважимо, що при аналізі соціально-психологічних факторів у першу чергу необхідно визначити, що у суспільстві відбулася зміна цінностей. Матеріальне благополуччя, незалежно від способів його досягнення, визначає цінність людини у значно більшій мірі ніж праця.

Різке зростання багатства вузького кола осіб породжує не тільки заздрощі, але і прагнення отримати такі ж, або сурогат таких же благ. Користь формує та визначає поведінку багатьох верств населення. Саме користь найбільш характерна ознака вчинених злочинів, не тільки проти власності але й багатьох інших [4, с. 408-409].

Відбувається посилення кримінального професіоналізму злочинців, об'єднання їх під прикриттям різних легальних структур, підвищення технічної оснащеності організованих злочинних угруповань, більш активне «самодетермінації злочинності», зростання кількості рецидивів, зростання корпоративної моралі та розповсюдження кримінальних стереотипів поведінки. Дуже часто використовуються виправдання такої поведінки «крадуть всі», «всі ми злочинці, тільки одних викрили, а інших ні».

Нажаль, продовжує залишатися високий поріг терпимості населення до злочинних проявів. Це обумовлено тим, що, з одного боку, перетворення злочинця у суспільній свідомості у багату, удачливу, достойну людину, поведінка якої потребує копіювання, з іншого боку - звикання до правопорушень, які спостерігає населення, а також невірою у здатність правоохоронної системи навести порядок, належним чином захистити від злочинних посягань. Необхідно також врахувати, що соціальна структура суспільства в Україні погіршена високою роллю раніше засуджених осіб (близько - 73544 злочинів було вчинено особами, які були раніше засудженими, у 2016 році - 72833 (динаміка 1,0\%) [5, с. 24]. Кримінальний досвід населення настільки великий, що саме він слугує джерелом самодетермінації злочинності.

На думку I. Б. Медицького, і з ним варто погодитись, моральним критеріям поведінки людини держава не приділяє значної уваги, у значній мірі «переклавши» цей обов’язок розвивати та реалізовувати у свідомості людей заповіді - «Не вбий», «Не вкради» на конфесії. Aле не можна вважати, що на сьогоднішній день церква та ії догми стали внутрішньою потребою суспільства. Сьогодні повинні «працювати» закладені у Конституції положення, як свобода вибору діяльності та професії, право на освіту, соціальне забезпечення та відшкодування завданої шкоди злочинними діями та ін. [6, с. 55].

На ситуацію, що склалася суттєво впливає потенціал правоохоронних органів, що здійснюють запобіжну діяльність, виявлення, реєстрацію, розкриття, розслідування злочинів, що посягають на власність, а також судів. Обмеженість ресурсного забезпечення правоохоронної та судової систем знижує їх запобіжні можливості.

Злочини проти власності у нашому суспільстві породжуються поляризацією доходів, інфляцією, економічною нестабільністю невлаштованістю та злиденністю деяких категорій населення. Ці фактори породжують в основному такі види, як дрібні та середні розкрадання чужого майна, грошей та інших цінностей, які в подальшому сприяють вчиненню розбійних нападів. Україна на сьогоднішній день бідна держава по рівню та якості життя свого населення: приблизно 35\% громадян України живуть за межею бідності. Третина погано харчується, не має нормального житла, можливостей достойно проводити вільний час та мати відпочинок. Вони живуть 3 відчуттям повної безнадії, неможливості щось змінити у своєму житті [7; $8]$.

Вчиненню досліджуваних злочинів сприяє високий рівень тривожності людей, які не впевнені у завтрашньому дні, а тому готові до вчинення корисливих дій, щоб відвести від себе проблеми матеріального характеру. Звичайно, тривожність можуть відчувати і забезпечені особи, але це відчуття дещо інакше. Воно головним чином пов'язане 3 нестабільністю фінансових процесів, діями конкурентів, кон'юнктурою ринку, ставленням правоохоронних органів [9, с. 129].

Антисуспільні погляди являють собою оціночні судження (стереотипи мислення) значної частини людей, що виражають прийнятне ставлення до кримінальних форм за- 


\section{Кримінальне право, кримінальний процес та криміналістика}

доволення повсякденних потреб та інтересів. Антисоціальні погляди формуються із світоглядних уявлень, моральних принципів, ціннісних орієнтацій, життєствердних інтересів великої кількості людей, об'єднаних однотипними умовами життя та схожими видами діяльності. На їх основі виробляється спільна позиція, що унормовуе кримінальну практику як вигідну і доступну для широкого загалу. Фактично, антисоціальні погляди виступають дороговказом, підштовхують на шлях вчинення злочинів тих, хто вагається. Також вони виправдовують кримінальну практику, надають їй ознак буденності.

Як вірно зазначає Б. М. Головкін, перераховані елементи деформацій суспільної свідомості найбільше впливають на морально незрілу низько-статусну молодь (14-29 років) та соціально неадаптовані верстви населення. Нерівномірним є їхнє територіальне поширення. Порівняно більше антисоціальні погляди, звичаї, традиції, установки підтримуються жителями східних і південних областей України, що тягне за собою нерівномірний регіональний розподіл злочинності в державі [1].

На думку С. А. Шалгунової, кримінальне насильство $\epsilon$ немов індикатором негативних тенденцій у суспільстві. Характер і масштаби такого насильства залежать від особливостей економічного, соціального, культурного розвитку. При цьому благополучним може бути тільки те суспільство, у якому рівень суспільної небезпеки та соціальної напруженості, що завжди пов'язано 3 кримінальною ситуацією, не перевищує визначеної межі. Обгрунтування ж цієї межі - проблема особлива. Як свідчить історія, злочинність і пов'язане 3 нею кримінальне насильство - явища вічні. Цілком викорінити злочинність неможливо. Можна по-різному називати злочини (ексцеси, соціальні факти, делікти), але не можна викорінити те, що у кожному конкретному випадку є наслідком протиріч між особою та суспільством, конфліктів між людьми. Можна й потрібно не допускати зростання злочинності вище тієї межі, перехід через яку призведе до суспільної небезпеки та соціальної напруженості. Останнім часом у нашій країні змінився традиційний підхід до визначення взаємозв'язків між злочинністю та іiі соціально-економічними умовами. При погіршенні цих умов масштаби кримінального насильства розширюються, відбувається зростання злочинності в цілому, а при поліпшенні - криміногенний рівень знижується. Наявність даного взаємозв'язку наочно демонструється сформованою у країні ситуацією [10, с. 249].

У процесі проведеного дослідження виокремлені головні причини та умови вчинення розбійних нападів на житло громадян, зокрема:

- загальне зростання злочинності в Україні та світі - 5,8\%;

- економічне становище в країні - 15,3\%;

- зростання безробіття й важке матеріальне становище у родині - 29,8\%;

- антисуспільна установка особи злочинця $-54 \%$;

- відсутність належного законодавчого забезпечення протидії цим злочинам - 5,1\%;

- нестабільність державної політики - 11 $(3,9 \%)$;

- незадовільна організація роботи правоохоронних органів та відсутність належного контролю за роботою правоохоронних органів - 5,7\%;

- легка нажива - 11,1\%; прибутковість вчинення розбійних нападів - $19 \%$

- відсутність належного контролю за особами, звільненими з місць позбавлення волі $-14 \%$;

- існування організованої злочинності $3,2 \%$.

Як зауважує В. В. Голіна, переважна більшість розбійних нападів на житло громадян пов'язана із попередньо сформованою антисуспільною, у тому числі злочинною діяльністю суб'єкта. Погоджуючись зі складністю проблеми причинного пояснення насильницьких злочинів, необхідно підтримати подальший пошук у мотиваційній сфері прихованих від науки глибинних патологічних рис особи злочинця, що знаходять свій прояв в агресивній або іншій деструктивній поведінці [11, с. 58]. У свою чергу суб'єктивні ознаки - свідомість і воля злочинців у цих випадках мають досить чітке узгодження, а мета й мотиви - відповідне спрямування та корисливе забарвлення. Підтвердженням цього, як правило, $\mathbf{E}$ 
формування злочинної діяльності, зокрема ретельне готування і планування вчинення цих злочинів. Органічна сукупність таких ознак надає підстави для висновку, що основною причиною вчинення цих злочинів є антисуспільна корисливо-насильницька установка осіб, які вчиняють розбійні напади на житло громадян.

У 1990-ті роки у країні існувала велика кількість організованих злочинних груп, які спеціалізувалися на розбійних нападах на житло підприємців. Причиною цього стало розширення числа об'єктів злочинного посягання, зростання нових форм діяльності тощо. Пізніше, як відомо, активність організованих злочинних груп істотно знизилася та дістала нових форм. Можна сказати, що інтерес цих груп майже повністю переключився на сферу економіки, а злочинні авторитети набули статусу успішних підприємців. Сьогодні, ми знову ж таки зіткнулися 3 проблемою 90-х років, з організованою корисливо-насильницькою злочинністю, що підтверджує розроблену кримінологічної наукою теорію про регулярну злочинну активність [12, с. 47]. Можна вести мову про те, що криміногенний потенціал суспільства знову переорієнтувався 3 традиційної злочинної діяльності на більш організований, професійний кримінальний бізнес.

Недоліки в організації соціально-економічних відносин, розбалансованості господарського (бюджетного) механізму держави, що призводить суспільство до тяжких кризових ситуацій й впливає на інші сторони суспільного буття є обставинами соціально-економічного характеру та відносять до факторів, що детермінують злочинність на соціологічному рівні.

Серед економічних чинників необхідно виділити спад суспільного виробництва i безробіття, яке набуло в Україні загрозливого стану. Так, на протязі 2008-2017 років реєструвалося у центрах зайнятості населення від 2 до 3,5 млн. осіб-безробітних (серед них 62\% - жінки, 32\% - молодь) [13].

Проте фахівці вважають, що реальний рівень безробіття у кілька разів вищий i становить до 40\% від загального числа працюючих. На кожне робоче місце претендує в середньому 15 осіб, в західних регіонах
України цей показник вищий в п’ять, а то й в шість разів.

Багато людей, які вважаються працюючими, фактично перебувають у довготривалих неоплачуваних відпустках, працюють неповний робочий тиждень і якщо врахувати і цю категорію, то рівень безробіття досягає 7 млн. чол. (13,4\% від працездатного населення). Як стверджують міжнародні експерти, допустимий рівень безробіття у суспільстві не повинен перевищувати 10\% населення у соціальне активному віці. Вищі показники загрожують соціальній стабільності у державі [13].

Усвідомлення молоддю відсутності перспектив у купівлі бажаного автомобіля або квартири, на нашу думку, здатне підштовхнути до вчинення злочину, зокрема розбійного нападу на житло громадян. Аналіз матеріалів кримінальних проваджень вказує на те, що люди 3 такою мотивацією вчиняють дані злочини. Це, підтверджується сформульованим у деяких підручниках 3 кримінології $[14 ; 15 ; 16]$ висновком про те, що у поведінці громадян спостерігається аномія або безнормативність, при якій вони не вірять у норми права і моралі й легко схиляються до протиправної, у тому числі злочинної поведінки, орієнтуючись на безвладдя і слабку ефективність правоохоронної системи. Такі довгострокові криміногенні соціально-психологічні тенденції, особливо серед молоді, на думку В. В. Аунєєва [17, с. 322], є дуже небезпечними і з ним важко не погодитися.

Зміни (деформації) у суспільній свідомості, що відбулися під впливом соціально-політичного та економічного чинника, втрата цінностей, проявилися у тому що суспільство перестало традиційно реагувати на злочинність і злочинця. Протиправні прояви стали нормою сучасного життя.

До психологічних факторів, що детермінують вчинення розбійних нападів на житло громадян, слід віднести втрату здебільшого населення довіри і готовність надавати підтримку правоохоронним органам, які займаються виявленням і розслідуванням цих злочинів. Це психологічне явище носить традиційний для населення характер, з огляду на слабку розвиненість інституту громадянської активності, на відміну від ряду зарубіжних 


\section{Кримінальне право, кримінальний процес та криміналістика}

країн. Більш того, як було встановлено у ході проведеного дослідження, розбійні напади на житло громадян структурно входять до складу організованої злочинності. У зв'язку з цим розраховувати на співпрацю з боку населення не доводиться.

При аналізі причин розбійних нападів необхідно зазначити, що завжди у кожному суспільстві або кожній державі є люди, які невдоволені своїм становищем і готові переступити закон, щоб це становище виправити у кращу сторону. Це може бути незадоволення і своїм матеріальним забезпеченням, яке проявляється навіть і у заможних людей. Вчиненню розглядуваних злочинів можуть сприяти такі загальні умови:

1) правові (протиріччя у законодавстві, у законах та підзаконних актах, відсутність чіткої кримінально-правової політики, слабка робота правоохоронних органів, i, що саме небезпечне, об'єднання співробітників цих органів 3 корисливими злочинцями. Вчинення розбійних нападів на житло громадян сприяє відсутність чіткої державної політики покарання по відношенню до осіб, які вчинили такі злочини. На жаль, особи, які вчинили такі злочини, а тим більше у ситуації з позбавленням життя інших людей повинні нести більш сувору кримінальну відповідальність, аж до довічного позбавлення волі);

2) етичні (у тому числі культ наживи у деяких категоріях населення, можливість високих прибутків після багатьох років заборон на них, при цьому забувають, що сучасна держава ніколи не забороняла отримання високих прибутків, вона забороняла використання для цього протиправних методів);

3) технічні (недосконалість технічних, організаційних та інших засобів запобігання, припинення вчинення розбійних нападів на житло громадян, а також взагалі відсутність цих засобів);

4) політичні (відсутність стабільної економічної, фінансової політики, що дозволяє недобросовісним людям використовувати різного роду умови для вчинення злочинів розбійних нападів).

Негативно позначається на кримінологічних показниках розбійних нападів на житло громадян негативні фактори у сфері правоохоронної діяльності державних органів. Зокрема, основне навантаження щодо запобігання і розслідування розбійних нападів на покладено на органи Національної поліції [18], які в даний час піддаються широкомасштабній реформі. Головною метою реалізованої реформи є створення сучасної та ефективної правоохоронної системи в Україні, але процес реформування має деякі негативні аспекти. Наприклад, зараз можна вести мову про дестабілізацію діяльності окремих підрозділів Національної поліції. Першопричиною цього є численні кадрові перестановки у різних підрозділах Національної поліції й ліквідація деяких з них, що негативно позначається на запобіганні окремим видам злочинів, у тому числі й корисливо-насильницького спрямування. Наприклад, недавно були ліквідовані підрозділи по боротьбі з організованою злочинністю, хоча, на нашу думку, за об'єктивних передумов для цього не було, а гучні злочинні напади останнього часу вказують на необхідність їх повернення.

До організаційних чинників, що детермінують вчинення розбійних нападів на житло громадян слід віднести доступність придбання в нашій країні газової та травматичної зброї, з використанням якої вчиняються дані злочини. Травматична вогнепальна зброя, на відміну від бойової й службової зброї володіє меншою вбивчою силою, з нею неможливо вести прицільний вогонь на великій відстані, але небезпека такої зброї, з точки зору умов вчинення даного виду розбійних нападів, полягає саме в його доступності для населення. Юридичні питання отримання ліцензії на покупку травматичної зброї врегульовані так, що практично будь-який громадянин може стати його власником [19; 20], а журналістські розслідування показують, наскільки формально лікарі ставляться до видачі медичної довідки на отримання зброї [21]. Вважаємо, що цій сфері, що відноситься до компетенції Національної поліції, необхідно навести порядок, бо практика показує, як часто травматична зброя знаходиться (і застосовується) у руках неврівноважених або зовсім психічно нездорових людей. У сукупності 3 вищевикладеними причинами ця умова 
є найпотужнішим чинником, що стимулює розбійні напади.

Продовження конфлікту на Сході країни супроводжуватиметься нелегальним поширенням зброї, боєприпасів та вибухівки, зростанням соціально-побутової невлаштованості осіб, які постраждали від збройного конфлікту, та перебувають у стресовому психологічному стані.

На основі вищевикладеного, необхідно зробити такі висновки:

1) фактори, що детермінують вчинення розбійних нападів на житло громадян, багато в чому є похідними від аналогічних факторів загальної корисливо-насильницької злочинності. В цілому дані фактори пов'язані із загальним зниженням керованості соціальними процесами, що виявилися у виникненні «тіньових» економічних відносин, розширенні числа джерел незаконних доходів, ускладненні механізму формування суспільної свідомості, у появі цілого ряду неврегульованих сегментів у правовому полі;

2) усю сукупність факторів, що детермінують вчинення розбійних нападів на житло громадян умовно можна поділити на шість груп: економічні, соціальні, політичні, організаційні, морально-психологічні і технічні. Основний вплив на аналізовані злочини здійснюють фактори, які стосуються економічної та організаційної груп.

у числі головних економічних факторів можна виділити такі явища як криміналізація економіки, диференціація і поляризація населення за доходами, безробіття і негативні процеси, які отримали свій розвиток в умовах фінансово-економічної кризи. Сутність стрижневих організаційних чинників можна звести до недоліків у роботі правоохоронних органів, які найбільше проявилися у рамках реформування;

3) виникнення кримінальних груп, що спеціалізуються на вчиненні розбійних нападів на житло громадян відбувається на основі кримінальної спільності окремих осіб, що прагнуть до отримання злочинного прибутку. У процесі спілкування таких осіб відбувається раціональний, емоційний і вольовий взаємовплив і взаємодія індивідів, яка досягається взаєморозумінням, створю- ються умови згуртованості й солідарності, що характеризують групову та колективну діяльність.

\section{入ітература}

1. Головкін Б. М. Причинність у системі детермінації злочинності. Теорія $i$ практика правознавства. 2014. Вип. 1 (5). URL: http:// nbuv.gov.ua/UJRN/tipp_2014_1_24

2. Кримінологія: навч. посіб. / О. М. Джужа, В. В. Василевич, Ю. Ф. Іванов та ін.; за заг. ред. О.М. Джужі. Київ: Прецедент, 2004. 208 c.

3. Хохряков Г. Ф. Криминология: учебник / отв. ред.. В. Н. Кудрявцев. М.: Юристь, $2000.511 \mathrm{c}$.

4. Профілактика злочинів: підручник / О. М. Джужа, В. В. Василевич, О. Ф. Гіда та ін.; за заг. ред. О. М. Джужи. Київ: Атіка, 2011.720 c.

5. Аналітична довідка про стан і основні тенденції криміногенної та безпекової ситуації в України у 2019 році. Київ: МВС України, 2020. 104 с.

6. Медицький I. Б. Вплив соціальних факторів на злочинність в умовах становлення незалежної Української держави : дис. ... канд. юрид. наук : 12.00.08. Івано-Франківськ, 2007. 223 с.

7. Мельниченко О. А. Підвищення рівня та якості життя населення: механізм державного регулювання: посібник. Харків: Вид-во ХарРІ НАДУ Магістр, 2008. 232 с.

8. Рівень життя населення України: довідник / НАН України. Ін-т демографії та соц. дослідж., Держ. ком. статистики України; за ред. А. М. Черенько. Київ: ТОВ «Видавництво «Консультант», 2006. 428 с.

9. Даньшин И. Н. Общетеоретические проблемы криминологии: монография. Харків: Прапор, 2005. 224 с.

10. Шалгунова С. А. Особа насильницького злочинця: монографія. Дніпропетровськ: Дніпроп. держ. ун-т внутр. справ;

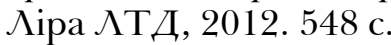

11. Голина В. В. Современные тенденции тяжкой насильственной преступности против личности и основные направления борьбы с нею. Проблеми боротьби з насильницькою злочинністю: зб. матеріалів наук.практ. конф. (Харків, 21-22 верес. 2001 р.). 


\section{Кримінальне право, кримінальний процес та криміналістика}

Харків: ПФ «Книжкове видавництво» $\Lambda$ ствиця Марії», 2001. С. 54-60.

12. Дрьомін В. Інституціональна теорія відтворення та протидії злочинності. Право Украӥни. 2009. №7. С. 45-51.

13. Населення та міграція. Ринок праці. Статистичні дані Державної служби статистики. URL: http://www.ukrstat.gov.ua/

14. Кримінологія: навч. посіб. / О. М. Джужа, В. В. Василевич, О. Г. Колб та ін.; за заг. ред. проф. О. М. Джужі. Київ : Атіка 2009. 312 c.

15. Закалюк А. П. Курс сучасної української кримінології: теорія і практика : у 3 кн. Київ : Ін Юре, 2007. Кн. 2 : Кримінологічна характеристика та запобігання вчиненню окремих видів злочинів. 712 с.

16. Иншаков С. М. Криминология: учебник. Москва: Юриспруденция, 2000. 432 с.

17. Аунеев В. В. Криминология: учебник для бакалавров. Москва: Издательство Юрайт, 2015. 686 с.

18. Про Національну поліцію: Закон України від 02 лип. 2015 р. № 580-VIII. Верховна Рада України. URL: http://zakon5.rada. gov.ua/laws/show/580-19

19. Про затвердження Аіцензійних умов провадження господарської діяльності з виробництва та ремонту вогнепальної зброї невійськового призначення і боєприпасів до неї, холодної зброї, пневматичної зброї калібру понад 4,5 міліметра і швидкістю польоту кулі понад 100 метрів на секунду, торгівлі вогнепальною зброєю невійськового призначення та боєприпасами до неї, холодною зброєю, пневматичною зброєю калібру понад 4,5 міліметра і швидкістю польоту кулі понад 100 метрів на секунду; виробництва спеціальних засобів, заряджених речовинами сльозоточивої та дратівної дії, індивідуального захисту, активної оборони та їх продажу: постанова Кабінету Міністрів України від 2 груд. 2015 р. № 1000. Верховна Рада України. URL: http://zakon2.rada.gov.ua/laws/ show/1000-2015-\%D0\%BF.

20. Інструкція про порядок виготовлення, придбання, зберігання, обліку, перевезення та використання вогнепальної, пневматичної, холодної і охолощеної зброї, пристроїв вітчизняного виробництва для відстрілу патронів, споряджених гумовими чи аналогічними за своїми властивостями метальними снарядами несмертельної дії, та патронів до них, а також боєприпасів до зброї, основних частин зброї та вибухових матеріалів: наказ МВС України від 21 серп. 1998 р. № 622. Верховна Рада Украӥни. URL: http://zakon2.rada.gov.ua/laws/show/z0637-98.

21. Ауцький Р. «Нікому то не треба», або як я проходив медогляд на отримання зброї. Волинъроst. 2017. 29 лип. URL: http:// www.volynpost.com/articles/161-nikomu-to-netreba-abo-iak-ia-prohodyla-medogliad.

\section{Детермінанти вчинення розбійних на- падів на житло громадян}

У статті здійснено розподіл детермінуючих факторів вчинення розбійних нападів на житло громадян на шість груп: економічні, соціальні, політичні, організаційні, морально-психологічні та технічні. Основний вплив на аналізовані злочини здійснюють причини та умови, що стосуються економічної (криміналізація економіки, диференціація і поляризація населення за доходами, безробіття і негативні процеси, які отримали свій розвиток в умовах фінансово-економічної кризи) та організаційної груп (реформування правоохоронних органів). Встановлено, що виникнення кримінальних груп, що спеціалізуються на вчиненні розбійних нападів на житло громадян відбувається на основі кримінальної спільності окремих осіб, що прагнуть до отримання злочинного прибутку. У процесі спілкування таких осіб відбувається раціональний, емоційний і вольовий взаємовплив та взаємодія індивідів, яка досягається взаєморозумінням, створюються умови згуртованості й солідарності, що характеризують групову й колективну діяльність.

Фактори, що детермінують вчинення розбійних нападів на житло громадян, багато в чому $є$ похідними від аналогічних факторів загальної корисливо-насильницької злочинності. В цілому дані фактори пов'язані із загальним зниженням керованості соціальними процесами, що виявилися у виникненні «тіньових» економічних відносин, розширенні числа джерел незаконних доходів, ускладненні механізму 
формування суспільної свідомості, у появі цілого ряду неврегульованих сегментів у правовому полі.

Усю сукупність факторів, що детермінують вчинення розбійних нападів на житло громадян умовно можна поділити на шість груп: економічні, соціальні, політичні, організаційні, морально-психологічні і технічні. Основний вплив на аналізовані злочини здійснюють фактори, які стосуються економічної та організаційної груп.

У числі головних економічних факторів можна виділити такі явища як криміналізація економіки, диференціація і поляризація населення за доходами, безробіття і негативні процеси, які отримали свій розвиток в умовах фінансово-економічної кризи. Сутність стрижневих організаційних чинників можна звести до недоліків у роботі правоохоронних органів, які найбільше проявилися у рамках реформування.

Виникнення кримінальних груп, що спеціалізуються на вчиненні розбійних нападів на житло громадян відбувається на основі кримінальної спільності окремих осіб, що прагнуть до отримання злочинного прибутку. У процесі спілкування таких осіб відбувається раціональний, емоційний і вольовий взаємовплив і взаємодія індивідів, яка досягається взаєморозумінням, створюються умови згуртованості й солідарності, що характеризують групову та колективну діяльність.

Ключові слова: розбій, власність, житло, детермінанти, причини, умови, запобігання.

\section{Determinants of Committing House Robbery}

The article divides the determinants of the perpetration of robbery on the housing of citizens into six groups: economic, social, political, organizational, moral and psychological and technical. The main influence on the analyzed crimes is exerted by economic causes and conditions (criminalization of the economy, differentiation and polarization of the population by income, unemployment and negative processes that have developed during the financial and economic crisis) and organizational groups (reform of law enforcement agencies). It is estab- lished that the emergence of criminal groups specializing in the perpetration of robbery on the housing of citizens occurs on the basis of the criminal community of individuals seeking criminal profits. In the process of communication of such persons there is a rational, emotional and volitional interaction and interaction of individuals, which is reached by mutual understanding, conditions of cohesion and solidarity characterizing group and collective activity are created.

The factors that determine the perpetration of robbery on the housing of citizens are in many respects derived from similar factors of general self-serving crime. In general, these factors are associated with a general decrease in the controllability of social processes that appeared in the emergence of «shadow» economic relations, the expansion of the number of sources of illicit income, complication of the mechanism of formation of public consciousness, in the emergence of a number of unregulated segments in the legal field.

The whole set of factors that determine the perpetration of robbery on the housing of citizens can be divided into six groups: economic, social, political, organizational, moral and psychological and technical. Factors affecting economic and organizational groups have a major impact on the crimes analyzed.

Among the main economic factors are the criminalization of the economy, the differentiation and polarization of the population by income, unemployment and the negative processes that have developed in the financial and economic crisis. The essence of the core organizational factors can be reduced to the shortcomings in the work of law enforcement agencies, which are most evident in the reform.

The emergence of criminal groups that specialize in committing robbery on the housing of citizens occurs on the basis of the criminal community of individuals seeking criminal profits. In the process of communication of such persons there is a rational, emotional and volitional interaction and interaction of individuals, which is reached by mutual understanding, conditions of cohesion and solidarity characterizing group and collective activity are created.

Keywords: robbery, property, housing, determinants, causes, conditions, prevention 